\title{
International Conference Ion Channels: Structure and Functions
}

\author{
DOI: $10.1134 / \mathrm{S} 1990747809010139$ \\ The scientific program will cover the following topics: \\ 1) Structure of ion channels; \\ 2) Role of ion channels in the regulation of cell function; \\ 3) Modeling of ion channels; \\ 4) Cell signaling.
}

RUSSIAN ACADEMY OF SCIENCES

Institute of Cytology RAS

Scientific Board on Cell Biology and Immunology RAS

Scientific Board on Biological Membranes

Society of Cell Biology RAS

194064, Russia, St.Petersburg, Tikhoretsky ave., 4 Tel.: (812)297-14-97, Fax: (812)297-03-41

Institute of Cytology RAS with the participation of Scientific Board on Biological Membranes, Scientific Board on Cell Biology and Immunology RAS, and Society of Cell Biology RAS have announced the Conference "Ion Channels: Structure and Function", dedicated to the Anniversary of Professor Galina MOZHAYEVA, the Associate Member of RAS. The Conference will be held on March 17-18, 2009, in the Institute of Cytology RAS (Tikhoretsky ave., 4, St. Petersburg, Russia).

The Conference will include the oral presentations and a poster session. The abstracts will be published in Biochemistry (Moscow), Series A: Membrane and Cell Biology.

The additional information about the Conference can be accorded by e-mail: ionchannel@mail.ru 